(1.5 $\mathrm{M}$ in hexane, $0.73 \mathrm{~mL}, 1.09 \mathrm{mmol}$ ) was injected dropwise into a stirred and cooled $\left(-78^{\circ} \mathrm{C}\right)$ solution of bromide $6(348 \mathrm{mg}, 1.09$ $\mathrm{mmol})$ in ether $(8 \mathrm{~mL})$. The mixture was stirred for an additional $20 \mathrm{~min}$, and aldehyde $7(176 \mathrm{mg}, 1.0 \mathrm{mmol})$ in ether $(3 \mathrm{~mL}+1$ $\mathrm{mL}$ rinse) was then added at $-78^{\circ} \mathrm{C}$ over ca. $3 \mathrm{~min}$. The reaction mixture was allowed to warm to $0^{\circ} \mathrm{C}$ over $2 \mathrm{~h}$. Saturated aqueous ammonium chloride $(10 \mathrm{~mL})$ was added, and the mixture was extracted with ether $(2 \times 15 \mathrm{~mL})$. The combined organic extracts were washed with brine and dried $\left(\mathrm{MgSO}_{4}\right)$. Evaporation of the solvent and flash chromatography of the residue over silica gel $(2 \times 15 \mathrm{~cm})$ with $1 \%$ ethyl acetate-dichloromethane gave alcohols 9 (371 mg, 89\%): IR (neat) $3540,2240,1585 \mathrm{~cm}^{-1}$; ${ }^{1} \mathrm{H}$ NMR $\left(\mathrm{CDCl}_{3}, 200 \mathrm{MHz}\right) \delta 2.22(\mathrm{~m}, 1 \mathrm{H}), 2.55-2.92(\mathrm{~m}, 2 \mathrm{H}), 3.15(\mathrm{~m}$ $1 \mathrm{H}), 3.33(2 \mathrm{~s}, 1: 2,3 \mathrm{H}), 3.95(\mathrm{~m}, 7 \mathrm{H}), 5.32(\mathrm{~m}, 1 \mathrm{H}), 6.45(\mathrm{~d}, J$ $=8 \mathrm{~Hz}, 1 \mathrm{H}), 6.68-6.90(\mathrm{~m}, 3 \mathrm{H}), 7.05(\mathrm{t}, J=7.5 \mathrm{~Hz}, 1 \mathrm{H}), 7.34$ $\left(\mathrm{m}, 5 \mathrm{H}\right.$ ); exact mass, $m / z 414.1827$ (calcd for $\mathrm{C}_{27} \mathrm{H}_{26} \mathrm{O}_{4}, 414.1824$ ). Anal. Calcd for $\mathrm{C}_{27} \mathrm{H}_{26} \mathrm{O}_{4} ; \mathrm{C}, 78.22 ; \mathrm{H}, 6.32$. Found: $\mathrm{C}, 78.06$; H, 6.38.

1-[3,6-Dimethoxy-2-(phenylethynyl)benzoyl]-2,3-dihydro-7-methoxy-1H-indene (10). Alcohols 9 (371 mg, 0.896 $\mathrm{mmol}$ ) in dichloromethane ( $5 \mathrm{~mL}+1 \mathrm{~mL}$ rinse) were added at room temperature to a stirred mixture of pyridinium chlorochromate $(772 \mathrm{mg}, 3.58 \mathrm{mmol})$ and $3-\AA$ molecular sieves $(1.79 \mathrm{~g}$, 8-12 mesh) in dichloromethane $(15 \mathrm{~mL})$. Stirring was continued for $4 \mathrm{~h}$, ether $(50 \mathrm{~mL})$ was added, and the brown suspension was filtered through a pad of Celite $(3 \times 6 \mathrm{~cm})$ which was washed well with 1:1 ether-dichloromethane. The combined filtrates were evaporated, and flash chromatography of the residue over silica gel $(2 \times 15 \mathrm{~cm})$ with dichloromethane gave ketone $10(280 \mathrm{mg}$, $75 \%$ ): IR (neat) $1690,1580 \mathrm{~cm}^{-1} ;{ }^{1} \mathrm{H} \mathrm{NMR}\left(\mathrm{CDCl}_{3}, 200 \mathrm{MHz}\right)$ $\delta 2.10-2.33(\mathrm{~m}, 1 \mathrm{H}), 2.60-2.92(\mathrm{~m}, 2 \mathrm{H}), 3.05-3.35(\mathrm{~m}, 1 \mathrm{H}), 3.45$ $(\mathrm{s}, 3 \mathrm{H}), 3.64(\mathrm{~s}, 3 \mathrm{H}), 3.82$ (s, 3H), 4.8 (dd, $J=8,2 \mathrm{~Hz}, 1 \mathrm{H}), 6.51$ $(\mathrm{d}, J=8 \mathrm{~Hz}, 1 \mathrm{H}), 6.8(\mathrm{~d}, J=8 \mathrm{~Hz}, 1 \mathrm{H}), 6.89(\mathrm{~s}, 2 \mathrm{H}), 7.10(\mathrm{t}$, $J=7.5 \mathrm{~Hz}, 1 \mathrm{H}), 7.32(\mathrm{~m}, 5 \mathrm{H}) ;{ }^{13} \mathrm{C} \mathrm{NMR}\left(\mathrm{CDCl}_{3}, 100.6 \mathrm{MHz}\right)$ $\delta 204.0,156.3,154.2,150.2,147.0,135.6,131.6,128.8,128.7,128.0$, $127.9,123.2,116.8,112.1,112.0,111.1,107.7,97.0,83.1,56.7,56.3$, $55.6,54.7,32.3,29.1$; exact mass, $m / z 412.1682$ (calcd for $\mathrm{C}_{27} \mathrm{H}_{24} \mathrm{O}_{4}$, 412.1668). Anal. Calcd for $\mathrm{C}_{27} \mathrm{H}_{24} \mathrm{O}_{4}: \mathrm{C}, 78.60 ; \mathrm{H}, 5.86$. Found: C, $78.68 ; \mathrm{H}, 5.88$.

1-[3,6-Dimethoxy-2-(phenylethynyl)benzoyl]-2,3-dihydro-7-methoxy-1-(phenylseleno)- $1 H$-indene (11). Ketone 10 (390 $\mathrm{mg}, 0.94 \mathrm{mmol}$ ) in THF ( $3 \mathrm{~mL}+1 \mathrm{~mL}$ rinse) was added over $5 \mathrm{~min}$ to a cold $\left(-78^{\circ} \mathrm{C}\right)$ solution of LDA [from diisopropylamine $(0.26 \mathrm{~mL}, 1.88 \mathrm{mmol})$ and $n$-butyllithium $(1.5 \mathrm{M}$ in hexane, $1.06 \mathrm{~mL}, 1.59 \mathrm{mmol})]$ in THF $(8 \mathrm{~mL})$. The yellow mixture was stirred at $-78^{\circ} \mathrm{C}$ for $1 \mathrm{~h}$, and phenylselenenyl chloride (574 $\mathrm{mg}, 2.82 \mathrm{mmol}$ ) in THF ( $3 \mathrm{~mL}+1 \mathrm{~mL}$ rinse) was added over 2 $\mathrm{min}$. The mixture was stirred at $-78^{\circ} \mathrm{C}$ for $1 \mathrm{~h}$ and then warmed to $-20^{\circ} \mathrm{C}$ over $30 \mathrm{~min}$. Saturated aqueous ammonium chloride $(10 \mathrm{~mL})$ was added followed by water $(5 \mathrm{~mL})$. The mixture was extracted with ether $(2 \times 20 \mathrm{~mL})$, and the combined extracts were washed with brine and dried $\left(\mathrm{MgSO}_{4}\right)$. Evaporation of the solvent and flash chromatography of the residue over silica gel $(3 \times 15$ $\mathrm{cm})$ with $30 \%$ ethyl acetate-hexane gave selenide $11(434 \mathrm{mg}$, $83 \%)$ : IR $\left(\mathrm{CHCl}_{3}\right) 2300,1670,1585,1460 \mathrm{~cm}^{-1} ;{ }^{1} \mathrm{H}$ NMR $\left(\mathrm{CDCl}_{3}\right.$, $200 \mathrm{MHz}) \delta 2.45-3.05(\mathrm{~m}, 4 \mathrm{H}), 3.28(\mathrm{~s}, 3 \mathrm{H}), 3.43(\mathrm{~s}, 3 \mathrm{H}), 3.90$ $(\mathrm{s}, 3 \mathrm{H}), 6.40(\mathrm{~d}, J=8 \mathrm{~Hz}, 1 \mathrm{H}), 6.55(\mathrm{~d}, J=7.5 \mathrm{~Hz}, 1 \mathrm{H}), 6.67$ $(\mathrm{d}, J=7.5 \mathrm{~Hz}, 1 \mathrm{H}), 6.80(\mathrm{~d}, J=8 \mathrm{~Hz}, 1 \mathrm{H}), 7.00-7.71(\mathrm{~m}, 11 \mathrm{H})$; ${ }^{13} \mathrm{C} \mathrm{NMR}\left(\mathrm{CDCl}_{3}, 100.6 \mathrm{MHz}\right) \delta 202.7,156.2,154.7,150.1,146.9$, $137.7,134.6,131.9,130.4,129.4,128.0,123.9,116.4,112.8,111.1$, $108.2,97.2,84.4,66.9,60.2,57.2,55.4,54.4,39.0,31.3,20.8,14.1$; mass spectrum, $m / z 568(\mathrm{M}), 411(\mathrm{M}-\mathrm{PhSe})$.

2,3-Dihydro-7-methoxy - $1 H$-indene- 1 -s piro- ${ }^{\prime}$ - $\left(3^{\prime}\right.$ benzylidene- $4^{\prime}, 7^{\prime}$-dimethoxy- $2 H$-inden- $1^{\prime}$-one) (14). Triphenyltin hydride ( $456 \mathrm{mg}, 1.30 \mathrm{mmol})$ in benzene $(3 \mathrm{~mL}+1 \mathrm{~mL}$ rinse) was added in one portion to a refluxing solution of selenide $11(425 \mathrm{mg}, 0.765 \mathrm{mmol})$ and AIBN (12 mg, $0.073 \mathrm{mmol})$ in benzene $(15 \mathrm{~mL})$. Refluxing was continued for $12 \mathrm{~h}$, and the solvent was evaporated. Flash chromatography of the residue over silica gel $(3 \times 15 \mathrm{~cm})$ with $40 \%$ ethyl acetate-hexane gave $14(252 \mathrm{mg}, 79 \%)$ : IR $\left(\mathrm{CHCl}_{3}\right) 1700,1585 \mathrm{~cm}^{-1} ;{ }^{1} \mathrm{H}$ NMR $\left(\mathrm{CDCl}_{3}\right.$, $200 \mathrm{MHz}) \delta 2.05-2.50(\mathrm{~m}, 3 \mathrm{H}), 4.0(\mathrm{~m}, 1 \mathrm{H}), 3.49(\mathrm{~s}, 3 \mathrm{H}), 3.91$ $(\mathrm{s}, 3 \mathrm{H}), 3.99(\mathrm{~s}, 3 \mathrm{H}), 6.40-7.25(\mathrm{~m}, 10 \mathrm{H}), 8.09(\mathrm{~s}, 1 \mathrm{H}) ;{ }^{13} \mathrm{C}$ NMR $\left(\mathrm{CDCl}_{3}, 100.6 \mathrm{MHz}\right) \delta 205.0,155.6,151.9,150.9,148.1,142.7,139.6$ $137.3,134.4,129.0,128.6,127.3,126.1,124.2,118.3,117.3,110.9$ $108.3,63.8,56.2,55.9,55.8,36.3,32.0$; exact mass, $m / z 412.1666$ (calcd for $\mathrm{C}_{27} \mathrm{H}_{24} \mathrm{O}_{4}, 412.1668$ ). Anal. Calcd for $\mathrm{C}_{27} \mathrm{H}_{24} \mathrm{O}_{4}: \mathrm{C}, 78.60$; $\mathrm{H}, 5.86$. Found: C, $78.22 ; \mathrm{H}, 5.71$.

2,3-Dihydro-7-methoxy-1H-indene-1-spiro-2' $-\left(4^{\prime}, 7^{\prime}\right.$-dimethoxy-2H -inden-1', $3^{\prime}$-dione) (15). An ozone-oxygen stream was bubbled through a solution of olefin $14(200 \mathrm{mg}, 0.485 \mathrm{mmol})$ in dry methanol $(7 \mathrm{~mL})$ at $-78^{\circ} \mathrm{C}$ until the starting material had just disappeared [ $2.5 \mathrm{~min}$, TLC (silica gel, $40 \%$ ethyl acetatehexane)]. Argon was passed through the solution for $5 \mathrm{~min}$ to remove the excess of ozone, and trimethyl phosphite $(0.17 \mathrm{~mL}$, $1.45 \mathrm{mmol}$ ) was injected. The cold bath was removed, and the solution was stirred overnight. Evaporation of the solvent and flash chromatography of the residue over silica gel $(2 \times 15 \mathrm{~cm})$ with $40 \%$ ethyl acetate-hexane gave diketone $15(100 \mathrm{mg}, 61 \%)$ : IR $\left(\mathrm{CHCl}_{3}\right) 1740,1705,1590 \mathrm{~cm}^{-1} ;{ }^{1} \mathrm{H} \mathrm{NMR}\left(\mathrm{CDCl}_{3}, 200 \mathrm{MHz}\right)$ $\delta 2.43(\mathrm{t}, J=7.5 \mathrm{~Hz}, 2 \mathrm{H}), 3.22(\mathrm{t}, J=7.5 \mathrm{~Hz}, 2 \mathrm{H}), 3.51(\mathrm{~s}, 3 \mathrm{H})$, $4.03(\mathrm{~s}, 6 \mathrm{H}), 6.65(\mathrm{~d}, J=8 \mathrm{~Hz}, 1 \mathrm{H}), 6.92(\mathrm{~d}, J=8 \mathrm{~Hz}, 1 \mathrm{H}), 7.20$ $(\mathrm{t}, J=8 \mathrm{~Hz}, 1 \mathrm{H}), 7.32(\mathrm{~s}, 2 \mathrm{H}) ;{ }^{13} \mathrm{C} \mathrm{NMR}\left(\mathrm{CDCl}_{3}, 100.6 \mathrm{MHz}\right)$ $\delta 200.4,155.1,151.0,148.4,129.9,129.6,128.2,119.9,117.2,108.3$, $65.3,56.6,55.2,35.3,32.3$; exact mass, $\mathrm{m} / \mathrm{z} 338.1148$ (calcd for $\mathrm{C}_{20} \mathrm{H}_{18} \mathrm{O}_{5}, 338.1149$ ). Anal. Calcd for $\mathrm{C}_{20} \mathrm{H}_{18} \mathrm{O}_{5}: \mathrm{C}, 70.98 ; \mathrm{H}, 5.36$. Found: C, 70.65; H, 5.53.

2,3-Dihydro-7-methoxy-1H -indene-1-spiro- $2^{\prime}-\left(4^{\prime}, 7^{\prime}-\mathrm{di}-\right.$ hydroxy-2H-inden-1 $1^{\prime}, 3^{\prime}$-dione) (16). Boron tribromide ( $1 \mathrm{M}$ in dichloromethane, $0.61 \mathrm{~mL}, 0.61 \mathrm{mmol}$ ) was injected over a period of $5 \mathrm{~min}$ to a cold $\left(-78^{\circ} \mathrm{C}\right)$ solution of diketone $15(23 \mathrm{mg}$, $0.068 \mathrm{mmol}$ ) in dichloromethane $(2 \mathrm{~mL})$. The cold bath was removed, and stirring was continued overnight. Water $(10 \mathrm{~mL})$ was added, and the mixture was extracted with dichloromethane $(2 \times 5 \mathrm{~mL})$. The combined organic extracts were dried $\left(\mathrm{MgSO}_{4}\right)$ and evaporated. Flash chromatography of the residue over silica gel $(1 \times 10 \mathrm{~cm})$ with dichloromethane gave $16(17.3 \mathrm{mg}, 85 \%)$ : IR $\left(\mathrm{CH}_{2} \mathrm{Cl}_{2}\right) 1720,1671,1595,1483 \mathrm{~cm}^{-1} ;{ }^{1} \mathrm{H}$ NMR (acetone- $d_{6}$, $400 \mathrm{MHz}) \delta 2.44(\mathrm{t}, J=8 \mathrm{~Hz}, 2 \mathrm{H}), 3.17(\mathrm{t}, J=8 \mathrm{~Hz}, 2 \mathrm{H}), 6.59$ $(\mathrm{d}, J=8 \mathrm{~Hz}, 1 \mathrm{H}), 6.80(\mathrm{~d}, J=8 \mathrm{~Hz}, 1 \mathrm{H}), 7.08(\mathrm{t}, J=8 \mathrm{~Hz}, 1$ $\mathrm{H}), 7.23(\mathrm{~s}, 2 \mathrm{H}) ;{ }^{13} \mathrm{C}$ NMR (acetone- $\left.d_{6}, 100.6 \mathrm{MHz}\right) \delta 204.1,153.5$, $149.7,149.1,130.5,128.2,126.5,124.6,116.5,113.3,78.8,35.1,32.7$; exact mass, $m / z 296.0693$ (calcd for $\mathrm{C}_{27} \mathrm{H}_{12} \mathrm{O}_{5}, 296.0681$ ). Anal. Calcd for $\mathrm{C}_{17} \mathrm{H}_{12} \mathrm{O}_{5}$ : C, 68.90; H, 4.08. Found: C, 68.56; H, 4.02 .

Acknowledgment. We thank the Natural Sciences and Engineering Research Council of Canada for financial support and the Alberta Heritage Foundation for Medical Research for a Postgraduate Scholarship (to S.M.B.).

\section{Acid- and Base-Catalyzed Ring-Opening Reactions of a Sterically Hindered Epoxide}

\author{
Herbert Mayr,* Rainer Koschinsky, Elfriede Will, and \\ Englbert Bäuml
}

Institut für Chemie der Medizinischen Universität $z u$ Lübeck, D-2400 Lübeck 1, Federal Republic of Germany

Received September 29, 1986

Epoxides are known to rearrange to carbonyl compounds under acidic conditions. ${ }^{1}$ When we tried to employ this reaction for the synthesis of octamethylcyclopentanone $(3)^{2}$ via the sequence shown in eq 1 , unexpected rearrangements took place, which we report in this paper.

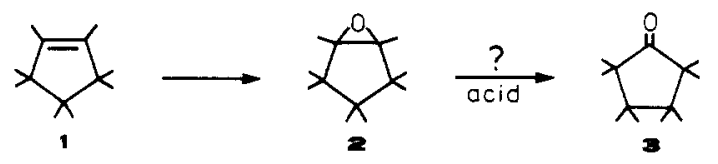

(1) Bartok, M.; Lang, K. L. In The Chemistry of Heterocyclic Compounds; (Eds. Weissberger, A., Taylor, E. C., Eds.; Wiley: New York, 1985; Vol. 42/III, Chapter 1 . 1162 .

2) Fitjer, L.; Wehle, D.; Scheuermann, H.-J. Chem. Ber. 1986, 119,

1987 American Chemical Society 
Scheme I

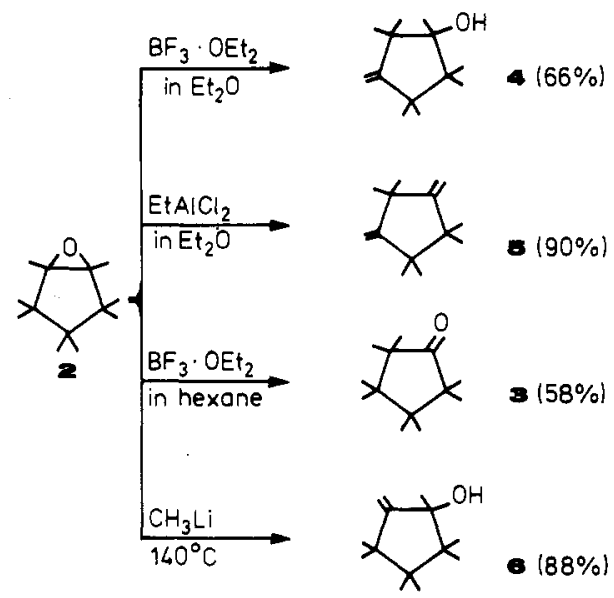

Scheme II
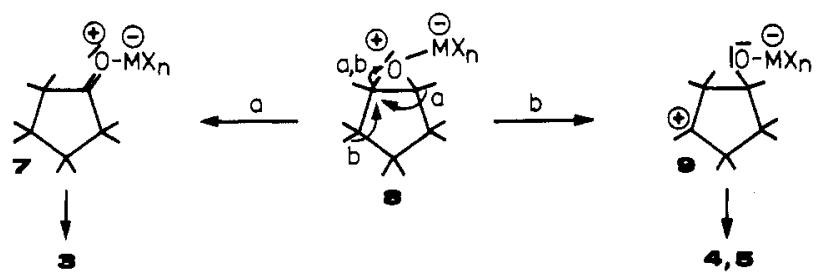

Octamethylcyclopentene $(1)^{3,4}$ was smoothly converted into epoxide 2 with either $m$-chloroperbenzoic acid or magnesium monoperoxyphthalate. ${ }^{5}$

Treatment of 2 with $\mathrm{BF}_{3} \cdot \mathrm{OEt}_{2}$ in diethyl ether at -20 ${ }^{\circ} \mathrm{C}$ yielded $66 \%$ of the homoallylic alcohol 4 along with $12 \%$ of the diene 5 (Scheme I). These two compounds were formed in a 1:1 ratio with small amounts of unidentified products when gaseous $\mathrm{BF}_{3}$ was bubbled through a solution of 2 in hexane at $0^{\circ} \mathrm{C}$. Various mixtures of 4,5 , and unknown compounds were also obtained when 2 was treated with $\mathrm{BCl}_{3}, \mathrm{TiCl}_{4}, \mathrm{H}_{2} \mathrm{SO}_{4}, \mathrm{HSO}_{3} \mathrm{~F}$, and trityl tetrafluoroborate under a variety of conditions. While 2 was inert toward diethylaluminum chloride in diethyl ether at $20^{\circ} \mathrm{C}$, it was almost quantitatively converted into diene 5 by ethylaluminum dichloride under the same conditions. Octamethylcyclopentanone (3) was finally produced when 2 was stirred in the heterogeneous mixture $\mathrm{BF}_{3} \cdot \mathrm{OEt}_{2}$ / hexane at $20^{\circ} \mathrm{C}$. Though 3 is thermodynamically more stable than 4 , attempts to convert 4 or 5 into 3 by treatment with aqueous proton acids have not been successful.

The reactivity of 2 toward organometallic compounds is also controlled by steric effects, and we have not been able to carry out a methylating ring-opening reaction of 2. While 2 was inert toward neat methyllithium up to 120 ${ }^{\circ} \mathrm{C}$, deprotonation of a methyl group with formation of the allylic alcohol 6 took place at $140^{\circ} \mathrm{C} .^{6}$

The transformation of $\mathbf{2}$ into 3-5 under acidic conditions is rationalized in Scheme II. When a carbon-oxygen bond in the complex 8 is breaking, two different methyl migrations are feasible. Methyl shift a yields the cyclopentanone complex 7 , which is thermodynamically favored over the 1,5-dipole 9 , the precursor of 4 and 5 . In spite

(3) Klein, H.; Mayr, H. Angew. Chem. 1981, 93, 1069; Angew. Chem., Int. Ed. Engl. 1981, 20, 1027. 2519 .

(4) Mayr, H.; Will, E.; Heigl, U. W.; Schade, C. Tetrahedron 1986, 42,

(5) Brougham, P.; Cummerson, D. A. Interox MMPP Applications Information $(I) ; 1984$.

(6) Analogous reaction with LDA: Pauluth, D.; Hoffman, H. M. R. Liebigs Ann. Chem. 1985, 756. For further examples, see ref 1. of that, path $\mathbf{b}$ is observed under the majority of conditions. This behavior may be attributed to an early transition state, which does not reflect the relative stabilities of 7 and 9 but the different release of steric strain. Path b may then be favored since in the early stage of this migration a perfectly eclipsed interaction between two $\mathrm{CC}$ bonds is abandoned. We do not understand, however, the relationship between reaction conditions and reaction products.

\section{Experimental Section}

General. Infrared spectra were recorded on a Beckmann Acculab 1 and a Shimadzu 435 IR spectrophotometer. NMR spectra were taken on a JEOL JNM-PS-100, a Varian EM 390, or a Varian XL 200 spectrometer. Chemical shifts $(\delta)$ were recorded relative to $\left(\mathrm{CH}_{3}\right)_{4} \mathrm{Si}$ as an internal standard. Mass spectra were recorded on a Varian MAT CH 4 spectrometer.

$1,2,2,3,3,4,4,5$-Octamethyl-6-oxabicyclo[3.1.0]hexane (2). A solution of octamethylcyclopentene (1) $(6.60 \mathrm{~g}, 36.6 \mathrm{mmol})$ in 30 $\mathrm{mL}$ of isopropyl alcohol was added dropwise to a vigorously stirred solution of magnesium monoperoxyphthalate hexahydrate (17.8 $\mathrm{g}, 36.0 \mathrm{mmol} \approx 2$ equiv) in $200 \mathrm{~mL}$ of isopropyl alcohol/water (v/v = 1/1) at ambient temperature. The mixture was stirred for $15 \mathrm{~h}, 500 \mathrm{~mL}$ of aqueous $\mathrm{K}_{2} \mathrm{CO}_{3}$ solution $(3 \%)$ was added, and the product was extracted with ether $(2 \times 100 \mathrm{~mL})$. The ether solutions were washed with $\mathrm{NaHSO}_{3}$ solution, dried over $\mathrm{Na}_{2} \mathrm{CO}_{3}$, and evaporated. Distillation $\left[68^{\circ} \mathrm{C}(6 \mathrm{mbar})\right]$ yielded $5.60 \mathrm{~g}(78 \%)$ of 2 , which solidified at room temperature. Low-temperature recrystallization from pentane gave colorless prisms with $\mathrm{mp}$ 43-46 ${ }^{\circ} \mathrm{C}$ : IR (neat): $2950,2860,1480,1450,1380,1370,1115,1090$, $855 \mathrm{~cm}^{-1} ;{ }^{1} \mathrm{H} \mathrm{NMR}\left(\mathrm{CCl}_{4}\right) \delta 0.68(\mathrm{~s}, 3 \mathrm{H}), 0.90,0.92(2 \mathrm{~s}, 15 \mathrm{H})$ $1.17(\mathrm{~s}, 6 \mathrm{H}) ;{ }^{13} \mathrm{C} \mathrm{NMR}\left(\mathrm{CDCl}_{3}\right) \delta 12.19\left(\mathrm{q}, 1,5-\mathrm{CH}_{3}\right), 20.26,24.72$ (2 q, 2,4- $\mathrm{CH}_{3}$ ), 22.02, $27.21\left(2 \mathrm{q}, 3-\mathrm{CH}_{3}\right), 43.89(\mathrm{~s}, \mathrm{C}-3), 44.96$ (s, $\mathrm{C}-2,4), 73.78$ (s, C-1,5); mass spectrum $(96 \mathrm{eV}), \mathrm{m} / z$ (relative intensity) $196\left(0.9, \mathrm{M}^{+}\right), 125(12), 111(100)$. Anal. Calcd for $\mathrm{C}_{13} \mathrm{H}_{24} \mathrm{O}$ (196.3): C, 79.53; $\mathrm{H}, 12.32$. Found: $\mathrm{C}, 79,54 ; \mathrm{H}, 12.39$.

2 was obtained in $80 \%$ yield from 1 and $m$-chloroperbenzoic acid according to a standard procedure. ${ }^{7}$

1,2,2,3,3,5,5-Heptamethyl-4-methylenecyclopentan-1-ol (4). Epoxide $2(2.94 \mathrm{~g}, 15.0 \mathrm{mmol})$ and $\mathrm{BF}_{3} \cdot \mathrm{OEt}_{2}(8 \mathrm{~mL}, 64 \mathrm{mmol})$ were allowed to react in $150 \mathrm{~mL}$ of anhydrous ether at $-20^{\circ} \mathrm{C}$ for 5 days. The orange solution was poured onto $400 \mathrm{~mL}$ of aqueous $\mathrm{NaHCO}_{3}$ solution. The ether phase was dried with $\mathrm{CaCl}_{2}$ and evaporated to give a mixture of 4 and $5\left(\approx 5: 1\right.$ by $\left.{ }^{1} \mathrm{H} N M R\right)$, which was separated by column chromatography (silica gel 60 (70-230 mesh), Merck, $l=20 \mathrm{~cm}$, i.d. $=2.5 \mathrm{~cm}$ ). Elution with $150 \mathrm{~mL}$ of hexane/ether $(\mathrm{v} / \mathrm{v}=99 / 1)$ yielded $0.32 \mathrm{~g}(12 \%)$ of 5 . Successive elution with $150 \mathrm{~mL}$ of hexane/dichloromethane $(\mathrm{v} / \mathrm{v}=1 / 2)$ gave $1.94 \mathrm{~g}(66 \%)$ of 4 . Colorless plates with $\mathrm{mp} 43-45^{\circ} \mathrm{C}$ (from hexane) were obtained: IR (Nujol) $3600,1640,920,880 \mathrm{~cm}^{-1} ;{ }^{1} \mathrm{H}$ $\operatorname{NMR}\left(\mathrm{CDCl}_{3}\right) \delta 0.82(\mathrm{~s}, 3 \mathrm{H}), 0.92(\mathrm{~s}, 3 \mathrm{H}), 0.97(\mathrm{~s}, 3 \mathrm{H}), 1.04(\mathrm{~s}$, $1 \mathrm{H}), 1.11(\mathrm{~s}, 3 \mathrm{H}), 1.12(\mathrm{~s}, 3 \mathrm{H}), 1.13(\mathrm{~s}, 3 \mathrm{H}), 1.21(\mathrm{~s}, 3 \mathrm{H}), 4.83$ $(\mathrm{s}, 1 \mathrm{H}), 4.85(\mathrm{~s}, 1 \mathrm{H}) ;{ }^{13} \mathrm{C} \mathrm{NMR}\left(\mathrm{CDCl}_{3}\right) \delta 17.66(\mathrm{q}), 21.57(\mathrm{q})$, 24.26 (q), 24.80 (q), 27.75 (q), 30.07 (q), 30.68 (q), 47.46 (s), 47.79 $(\mathrm{s}), 49.08(\mathrm{~s}), 84.59(\mathrm{~s}), 103.23(\mathrm{t}), 171.98(\mathrm{~s})$; mass spectrum $(96$ $\mathrm{eV}) ; m / z$ (relative intensity) $196\left(11, \mathrm{M}^{+}\right), 181(14), 178(5), 163$ (14), 153 (12), $111(100), 110$ (67), 95 (65). Anal. Calcd for $\mathrm{C}_{13} \mathrm{H}_{24} \mathrm{O}$ (196.3): C, 79.53; C, 12.32. Found: C, 79.61; H, 12.36 .

$1,1,2,2,4,4-H e x a m e t h y l-3,5$-bis(methylene)cyclopentane (5). A $50 \%$ solution of $\mathrm{C}_{2} \mathrm{H}_{5} \mathrm{AlCl}_{2}$ in hexane $(15 \mathrm{~mL}, \approx 60 \mathrm{mmol})$ was added to a solution of $2(1.96 \mathrm{~g}, 10.0 \mathrm{mmol})$ in $200 \mathrm{~mL}$ of anhydrous ether (ambient temperature, $\mathrm{N}_{2}$ atmosphere). The mixture, which turned yellow, was stored at room temperature for $60 \mathrm{~h}$ and was then slowly poured onto $200 \mathrm{~mL}$ of water. After separation of the layers, the aqueous layer was extracted with 100 $\mathrm{mL}$ of ether. The organic fractions were dried with $\mathrm{CaCl}_{2}$, and the solvent was evaporated to yield crude 5. According to ${ }^{1} \mathrm{H}$ NMR the product was contaminated by $\approx 5 \%$ of 3 , which was removed by filtration of the mixture over silica gel (eluent hexane/ether $=99 / 1)$. Distillation $\left[30-35^{\circ} \mathrm{C}\right.$ (bath) $\left.(0.1 \mathrm{mbar})\right]$ yielded 1.60 $\mathrm{g}(90 \%)$ of $\mathbf{5}$ as a colorless liquid, which solidified in the freezer

(7) Organikum, 15th ed,; VEB Deutscher Verlag der Wissenschaften: Berlin, 1977; p 324 . 
$\left(-20^{\circ} \mathrm{C}\right)$ : IR (neat) $3080,2970,2870,1640,1460,1450,1420,1380$, $1365,1180,1140,880,780,680 \mathrm{~cm}^{-1} ;{ }^{1} \mathrm{H}$ NMR $\left(\mathrm{CCl}_{4}\right) \delta 0.91(\mathrm{~s}$, $12 \mathrm{H}), 1.20(\mathrm{~s}, 6 \mathrm{H}), 4.77(\mathrm{~s}, 2 \mathrm{H}), 4.82(\mathrm{~s}, 2 \mathrm{H}) ;{ }^{13} \mathrm{C} \mathrm{NMR}\left(\mathrm{CDCl}_{3}\right)$ $\delta 24.21\left(\mathrm{q}, 1,2-\mathrm{CH}_{3}\right), 32.94\left(\mathrm{q}, 4-\mathrm{CH}_{3}\right), 43.80$ (s, C-4), 47.66 (s, C-1,2), $102.71(\mathrm{t}), 169.60(\mathrm{~s})$; mass spectrum $(70 \mathrm{eV}), \mathrm{m} / z$ (relative intensity) $178\left(11, \mathrm{M}^{+}\right), 163(100), 135(38), 122(45), 121(60)$. Anal. Calcd for $\mathrm{C}_{13} \mathrm{H}_{22}$ (178.3): C, 87.56; H, 12.44. Found: C, 87.36; $\mathrm{H}, 12.64$.

Octamethylcyclopentanone (3). A solution of 2 (1.96 g, 10.0 $\mathrm{mmol}$ ) in $100 \mathrm{~mL}$ of hexane was added dropwise $(\approx 60 \mathrm{~min})$ to a rapidly stirred mixture of $10 \mathrm{~mL}$ of $\mathrm{BF}_{3} \cdot \mathrm{OEt}_{2}(80 \mathrm{mmol})$ in 300 $\mathrm{mL}$ of hexane at ambient temperature. The mixture was stirred for another $30 \mathrm{~min}$ and then hydrolyzed with $400 \mathrm{~mL}$ of aqueous $\mathrm{NaHCO}_{3}$ solution $(5 \%)$. The organic layer was dried with $\mathrm{CaCl}_{2}$ and evaporated to give 3 contaminated by traces of 5 , which were removed by column chromatography: $\mathbf{5}$ was washed from a column of silica gel $60(l=15 \mathrm{~cm}$, i.d. $=2.5 \mathrm{~cm})$ with $100 \mathrm{~mL}$ of hexane/ether $(\mathrm{v} / \mathrm{v}=99 / 1) .3(1.13 \mathrm{~g}, 58 \%)$ was then eluted with $150 \mathrm{~mL}$ of $\mathrm{CH}_{2} \mathrm{Cl}_{2}$. Analytical data of 3 is given in ref 2 .

1,2,2,3,3,4,4-Heptamethyl-5-methylenecyclopentan-1-ol (6). Compound $2(0.98 \mathrm{~g}, 5.0 \mathrm{mmol})$ was added to $10 \mathrm{~mL}$ of a $1.6 \mathrm{M}$ solution of $\mathrm{CH}_{3} \mathrm{Li}$ in ether. The ether was distilled off, and the residue was heated at $140^{\circ} \mathrm{C}$ for $2 \mathrm{~h}$ to give a brownish mixture, which was cooled and treated with $5 \mathrm{~mL}$ of the $\mathrm{CH}_{3} \mathrm{Li}$ solution as before. After the mixture was cooled, $10 \mathrm{~mL}$ of ether was added, and the solution was hydrolyzed with $10 \mathrm{~mL}$ of concentrated aqueous $\mathrm{NH}_{4} \mathrm{Cl}$ solution. The organic layer was dried with $\mathrm{CaCl}_{2}$ and evaporated to give a mixture of 6 and some nonidentified byproducts. The mixture was separated by column chromatography (silica gel $60, l=15 \mathrm{~cm}$, i.d. $=2.5 \mathrm{~cm}$ ). After elution of the byproducts with $100 \mathrm{~mL}$ of hexane/ether $(\mathrm{v} / \mathrm{v}=99 / 1)$, pure $6(0.86 \mathrm{~g}, 88 \%)$ was washed from the column with hexane/ether $(v / v=92 / 8)$. Colorless plates with $\mathrm{mp} 40-45^{\circ} \mathrm{C}$ (from pentane) were obtained: IR (neat) $3330,2950,1450,1380,1075,910,735$ $\mathrm{cm}^{-1} ;{ }^{1} \mathrm{H} \mathrm{NMR}\left(\mathrm{CDCl}_{3}\right) \delta 0.82(\mathrm{~s}, 3 \mathrm{H}), 0.84(\mathrm{~s}, 3 \mathrm{H}), 0.93(\mathrm{~s}, 3 \mathrm{H})$, $1.07(\mathrm{~s}, 3 \mathrm{H}), 1.09(\mathrm{~s}, 3 \mathrm{H}), 1.11(\mathrm{~s}, 3 \mathrm{H}), 1.17(\mathrm{~s}, 1 \mathrm{H}), 1.27(\mathrm{~s}, 3$ $\mathrm{H}), 4.95(\mathrm{~s}, 1 \mathrm{H}), 5.18(\mathrm{~s}, 1 \mathrm{H}) ;{ }^{13} \mathrm{C}$ NMR $\left(\mathrm{CDCl}_{3}\right) \delta 18.67(\mathrm{q}), 22.54$ (q), 23.73 (q), 23.97 (q), 25.60 (q), 29.96 (q), 30.53 (q), 45.00 (s), $46.17(\mathrm{~s}), 48.79(\mathrm{~s}), 82.27(\mathrm{~s}), 105.84(\mathrm{t}), 169.77(\mathrm{~s})$. Anal. Calcd for $\mathrm{C}_{13} \mathrm{H}_{24} \mathrm{O}(196.3)$ : C, $79.52 ; \mathrm{H}, 12.32$. Found: $\mathrm{C}, 78.77 ; \mathrm{H}, 12.15$.

Acknowledgment. We thank Diana Schnoor for experimental assistance and the Fonds der Chemischen Industrie for financial support.

\section{2-Halogenated Purine Nucleosides: Synthesis and Reactivity ${ }^{1}$}

Vasu Nair,* David A. Young, and Raymond DeSilvia, Jr. ${ }^{2}$

Department of Chemistry, University of Iowa, Iowa City, Iowa 52242

Received August 5, 1986

Although considerable attention has been devoted to the synthesis and reactions of 6-halogenated purine nucleosides, ${ }^{3-7}$ the same cannot be said for the corresponding 2-halogenated compounds. 8,9 This is in part due to limitations in synthetic accessibility to this class of nucleosides. 2-Halogenated purines are potentially key synthetic intermediates to a variety of novel 2 -substituted purine

(1) Presented in part at the 10th International Congress of Heterocyclic Chemistry, Waterloo, Canada, August 1985

(2) Deceased, May 22, 1986.

(3) Lister, J. H. In "Purines" Fused Pyrimidines; Brown, D. J., Ed.; Wiley-Interscience: New York, 1971; Part II, Chapters 2, 4.

(4) Townsend, L. B. In Nucleoside Analogues; Walker, R. T., De

Clercq, E., Eckstein, F., Eds.; Plenum: New York, 1979; pp 193-223.

(5) Nair, V.; Richardson, S. G. J. Org. Chem. 1980, 45, 3969.

(6) Elion, G. B. J. Org. Chem. 1962, 27, 2478.

(7) Giner-Sorolla, A.; Bendich, F. H. J. Med. Chem. 1965, 8, 667

(8) Kawana, M.; Rousseau, R. J.; Robins, R. K. J. Med. Chem. 1972 15,214 .

(9) Schaeffer, H. J.; Thomas, H. J. J. Am. Chem. Soc. 1958, 80, 4896.

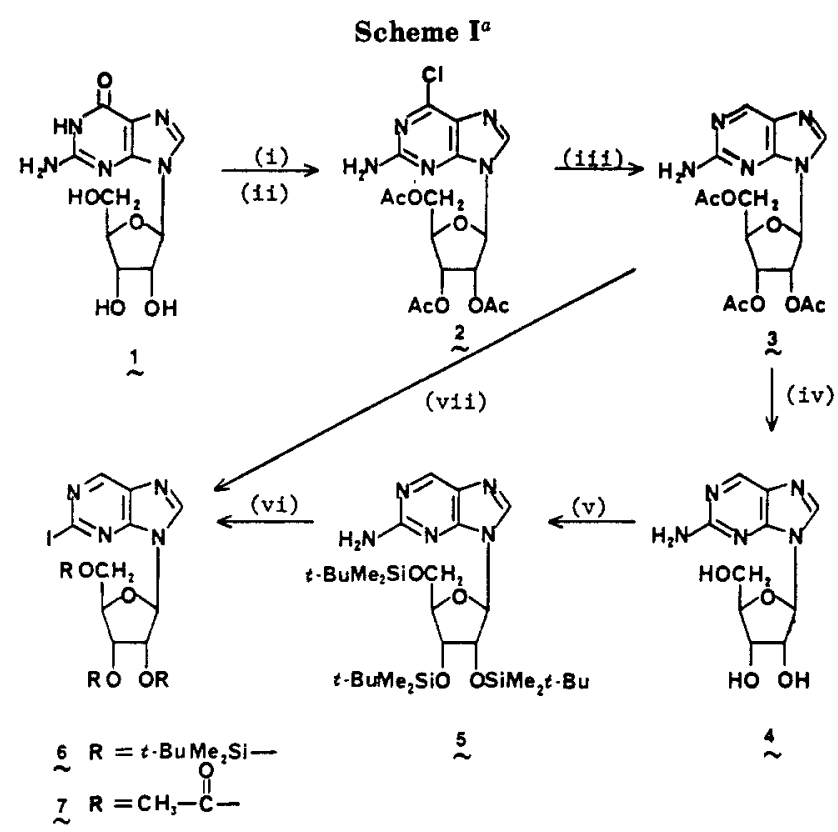

a (i) $\mathrm{Ac}_{2} \mathrm{O},\left(\mathrm{C}_{2} \mathrm{H}_{5}\right)_{3} \mathrm{~N}, \mathrm{~N}, \mathrm{~N}$-(dimethylamino)pyridine; (ii) $\mathrm{POCl}_{3}$, $N, N$-diethylaniline, $\Delta$; (iii) $\left(\mathrm{C}_{2} \mathrm{H}_{5}\right)_{3} \mathrm{~N}$, THF, hv; (iv) $\mathrm{NH}_{3}, \mathrm{C}_{2} \mathrm{H}_{5} \mathrm{OH}$; (v) $t$ - $\mathrm{Bu}\left(\mathrm{CH}_{3}\right)_{2} \mathrm{SiCl}$, imidazole, DMF, $\Delta$; (vi) $n-\mathrm{C}_{5} \mathrm{H}_{11} \mathrm{ONO}, \mathrm{CH}_{2} \mathrm{I}_{2}$, $\left(\mathrm{CH}_{3}\right)_{3} \mathrm{SiI}$, hexane, $\Delta$; (vii) $n-\mathrm{C}_{5} \mathrm{H}_{11} \mathrm{ONO}, \mathrm{CH}_{2} \mathrm{I}_{2}, \mathrm{CH}_{3} \mathrm{CN}$.

nucleosides. A logical approach to 2-halogenated purines may be via the corresponding 2-amino compound. 2Amino-9- $\beta$-D-ribofuranosylpurine is an important biologically active nucleoside. It is a potent inhibitor of a number of purine metabolizing enzymes including adenosine deaminase, ${ }^{10}$ purine nucleoside phosphorylase, ${ }^{11}$ and adenosine kinase. ${ }^{12}$ It is incorporated in $E$. coli and phage T4 DNA. ${ }^{13,14}$ However, an efficient general method for the preparation of this compound is not currently available. Previous syntheses involved, as the key step, the hydrogenolysis of the corresponding 6-chloro compound (protected) using $\mathrm{Pd} / \mathrm{C}$ and hydrogen, treatment of the protected 6-thio compound with Raney nickel in water, and coupling of a halogenated sugar with protected 2-aminopurine in the presence of mercuric chloride. ${ }^{9,13,15,16}$ Photochemical methods are rarely used in nucleoside synthesis. We wish to report a high yielding and reproducible photochemical synthesis of 2-aminopurine nucleoside, its conversion to the corresponding novel 2-halogenated compound, and the synthetic utilization of the latter.

The starting material for the synthesis was guanosine (1) which was selectively acetylated in $93 \%$ yield by using acetic anhydride, triethylamine, and 4-(dimethylamino)pyridine in acetonitrile. ${ }^{17}$ Treatment of the triacetylated guanosine with phosphorus oxychloride and $N, N$-diethylaniline at $70^{\circ} \mathrm{C}$ for $1 \mathrm{~h}$ gave the 6-chloro compound

(10) Simon, L. N.; Baur, R. J.; Tolman, R. L.; Robins, R. K. Biochemistry $1970,9,573$.

(11) Doskocil, J.; Holy, A. Collect. Czech. Chem. Commun. 1977, 42, 370.

(12) Miller, R. L.: Adamczk, D. L.; Miller, W. H.; Koszalka, G. W.; Rideout, J. L.; Beacham, L. M., III; Chao, E. Y.; Haggerty, J. J.; Krenitsky, T. A.; Elion, G. B. J. Biol. Chem. 1979, 254, 2346.

(13) Janion, C.; Shugar, D. Acta Biochem. Pol. 1973, 20, 271.

(14) Gottschting, H.; Freese, E. Z. Naturforsch., B: Anorg. Chem., Org. Chem., Biochem., Biophys. Biol. 1961, 16B, 515.

(15) Fox, J. J.; Wempen, I.; Hampton, A.; Doerr, I. L. J. Am. Chem. Soc. $1958,80,1669$.

(16) Vickers, R. S.; Gerster, J. F.; Robins, R. K. In Synthetic Procedures in Nucleic Acid Chemistry; Zorbach, W. W., Tipson, R. S., Eds.; Interscience: New York, 1968, Vol. 1, p 244.

(17) Matsuda, A.; Shinozaki, M.; Suzuki, M.; Watanabe, K.; Miyasaka, T. Synthesis 1986, 385 . 